\title{
How Did the Profitability of the Japanese Firms Change? Before, During, and After the Lehman Shock in the US
}

\author{
Chikashi Tsuji ${ }^{1}$ \\ ${ }^{1}$ Professor, Faculty of Economics, Chuo University, 742-1 Higashinakano Hachioji-shi, Tokyo 192-0393 Japan \\ Correspondence: Chikashi Tsuji, Faculty of Economics, Chuo University, 742-1 Higashinakano Hachioji-shi, Tokyo \\ 192-0393 Japan. Tel: 81-42-674-2211 E-mail: mail_sec_low@minos.ocn.ne.jp
}

Received: February 21, 2015

Accepted: March 3, 2015

Online Published: March 4, 2015

doi:10.5430/bmr.v4n1p74

URL: http://dx.doi.org/10.5430/bmr.v4n1p74

\begin{abstract}
This paper investigates the time-series changes of the profitability of the Japanese corporations by focusing, in particular, on their differences in the periods before, during, and after the US Lehman shock. Evidence derived from our analyses using the Japanese time-series data is summarized as follows. 1) First, around the Lehman shock, the ordinary income to equity capital ratio, total asset turnover, and the sales per employee of the Japanese corporations dropped, and after the shock, they recovered; however, their levels did not exceed the levels before the Lehman shock. 2) Second, during the period of the Lehman shock, the labor costs to sales ratio of the Japanese corporations unfavorably increased; however, after the shock, it recovered to almost the same level as that before the Lehman shock. 3) Third, during the Lehman shock, the ordinary income to sales ratio, ordinary income per employee, and ordinary income to labor costs of the Japanese corporations declined; however, after the shock, they recovered and improved to the levels that exceeded those before the Lehman shock. 4) Fourth, the financial leverage of the Japanese corporations continuously decreased regardless of the effects of the Lehman shock.
\end{abstract}

Keywords: Corporate profitability, Financial ratio, Japanese firms, Lehman shock

\section{Introduction}

How did the US Lehman shock affect the Japanese firms? How were the financial strength and profitability of the Japanese firms in the periods before, during, and after the Lehman shock? Did the Japanese firms fully recover from the negative effects of the US Lehman shock? These are interesting questions both for practitioners and academicians; however, regardless of the importance of these issues, it seems to be difficult to find the studies that investigated and compared the financial state of the Japanese firms in the periods before, during, and after the US Lehman shock in the existing literature.

Based on the situation documented above, using the Japanese time-series data, this paper investigates the time-series changes of the profitability of the Japanese firms by focusing, in particular, on their differences in the periods before, during, and after the US Lehman shock. Evidence derived from our empirical analyses is summarized as follows. 1) First, around the Lehman shock, the ordinary income to equity capital ratio, total asset turnover, and the sales per employee of the Japanese firms declined, and after the shock, they recovered; however, their levels did not exceed those levels before the Lehman shock. 2) Second, during the period of the Lehman shock, the labor costs to sales ratio of the Japanese firms unfavorably increased; however, after the shock, it declined to almost the same level as that before the Lehman shock. 3) Third, during the Lehman shock, the ordinary income to sales ratio, ordinary income per employee, and ordinary income to labor costs of the Japanese firms dropped; however, after the shock, they recovered and improved to the levels that exceeded those before the Lehman shock. 4) Fourth, the financial leverage of the Japanese firms continuously decreased regardless of the effects of the Lehman shock.

The rest of the paper is organized as follows. Section 2 reviews the recent existing literature that analyzed financial ratios, Section 3 documents our data and variables we analyze in this paper, and Section 4 explains our analyzing methodology. After that, Section 5 presents an overview, Section 6 describes the further evidence obtained from this study, and Section 7 concludes the paper.

\section{Literature Review}

This section reviews the interesting studies related to the financial ratio analyses by focusing on the very recent 
researches. First, Denis (2011) provided an overview on the financial flexibility and corporate liquidity. This overview emphasized the importance for studying the determinants and consequences of corporate cash holdings, as well as the impact of flexibility considerations of payout policies and corporate capital structure. Lin et al. (2014) analyzed the financially distressed prediction (FDP) problem and they proposed an integrated approach to solve the FDP problem. They also showed that their proposed method outperformed traditional models. Further, using the data of Italian corporations, Ciampi et al. (2014) found that corporate governance variables significantly improved the default prediction accuracy rates as to the small enterprises.

Moreover, Rapp et al. (2014) revealed that corporations for which shareholders considered financial flexibility more valuable had lower dividend payouts, preferred share buybacks, and had lower debt ratios. Further, using the data of the corporations in Thailand and Malaysia, Selahudin et al. (2014) researched the differences of earnings management, debt ratio, financial distress, and free cash flow of the corporations in the two countries. Sahin and Sahin (2014) investigated the Turkish firms and pointed out that the high degree of the corporate liability dollarization increased the firms' costs in Turkey. They constructed sectorial liability dollarization ratios of the Turkish firms and analyzed them over the four years from 2009 to 2012.

Table 1. Descriptive statistics of the analyzed variables as to the Japanese firms: For the full sample period from January 2000 to September 2014

\begin{tabular}{|c|c|c|c|c|}
\hline & $\begin{array}{l}\text { Ordinary income to } \\
\text { equity capital ratio }\end{array}$ & $\begin{array}{l}\text { Ordinary income to } \\
\text { sales ratio }\end{array}$ & Total asset turnover & Financial leverage \\
\hline Mean & 2.7013 & 3.4444 & 0.2567 & 3.0976 \\
\hline Median & 2.7959 & 3.5772 & 0.2603 & 2.9270 \\
\hline Maximum & 3.4695 & 4.9937 & 0.2882 & 4.1668 \\
\hline Minimum & 0.8893 & 1.3810 & 0.2287 & 2.4939 \\
\hline Std. Dev. & 0.5533 & 0.7720 & 0.0160 & 0.4676 \\
\hline Skewness & -1.1432 & -0.3354 & -0.0215 & 0.6505 \\
\hline Kurtosis & 4.4939 & 3.1084 & 1.8889 & 2.0753 \\
\hline \multirow[t]{2}{*}{ Observations } & 177 & 177 & 177 & 177 \\
\hline & $\begin{array}{l}\text { Ordinary income per } \\
\text { employee }\end{array}$ & $\begin{array}{l}\text { Ordinary income to } \\
\text { labor costs }\end{array}$ & $\begin{array}{l}\text { Labor costs to sales } \\
\text { ratio }\end{array}$ & Sales per employee \\
\hline Mean & 0.0003 & 26.9096 & 12.9061 & 0.0101 \\
\hline Median & 0.0004 & 27.9460 & 12.9095 & 0.0101 \\
\hline Maximum & 0.0005 & 40.1554 & 13.9750 & 0.0108 \\
\hline Minimum & 0.0001 & 9.9583 & 11.5728 & 0.0088 \\
\hline Std. Dev. & 0.0001 & 6.7203 & 0.6085 & 0.0004 \\
\hline Skewness & -0.3695 & -0.2892 & -0.1913 & -0.5666 \\
\hline Kurtosis & 3.1285 & 2.6734 & 2.0449 & 2.8805 \\
\hline Observations & 177 & 177 & 177 & 177 \\
\hline
\end{tabular}

Notes: This table presents the descriptive statistics of the variables analyzed in this study. In this table, 'Std. Dev.' denotes the value of standard deviation. Samples are monthly and our full sample period spans January 2000 to September 2014.

In addition, an interesting study by du Jardin (2015) proposed a new bankruptcy prediction procedure, and this study demonstrated that the proposed procedure predicted bankruptcy better at a three-year horizon than the other common models. Tian et al. (2015) suggested that some financial ratio variables constructed from only accounting data had significant incremental information as to future corporate default risk. Furthermore, Ritz and Walther (2015) considered whether funding uncertainty can explain banks' behavior during financial crises. Their study theoretically showed that when banks face the funding uncertainty, banks reduce the lending volumes, balance sheets, and hence their profitability decreases. 
In this section, we reviewed the very recent literature that employed the financial ratio analyses. However, even if we search older studies, it seems to be difficult to find the research that investigated and compared the financial state of the Japanese firms in the periods before, during, and after the US Lehman shock.

Panel A. Ordinary income to equity capital ratio

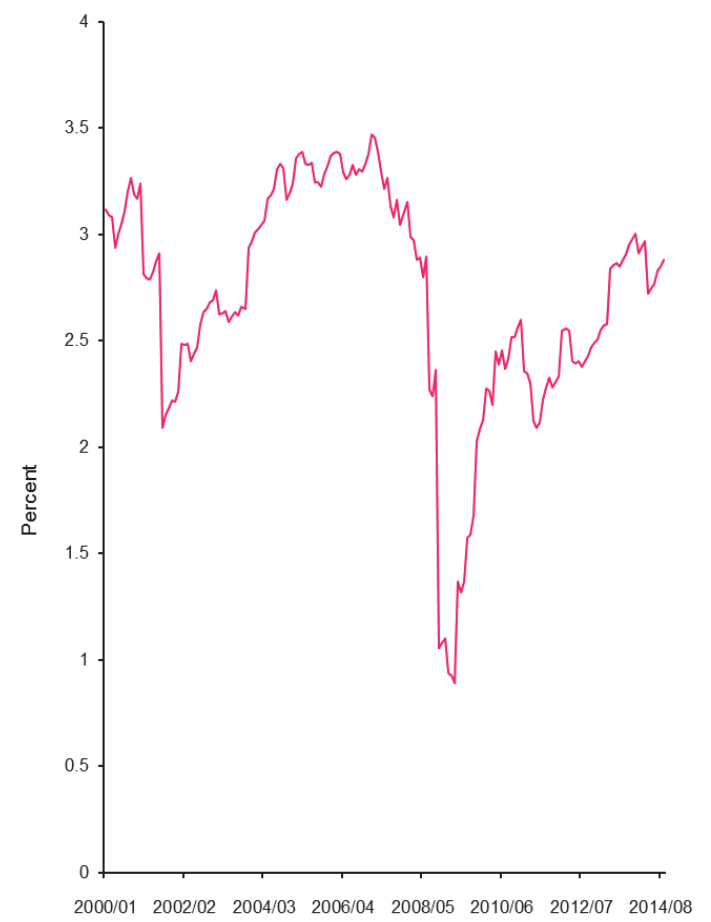

Panel C. Total asset turnover

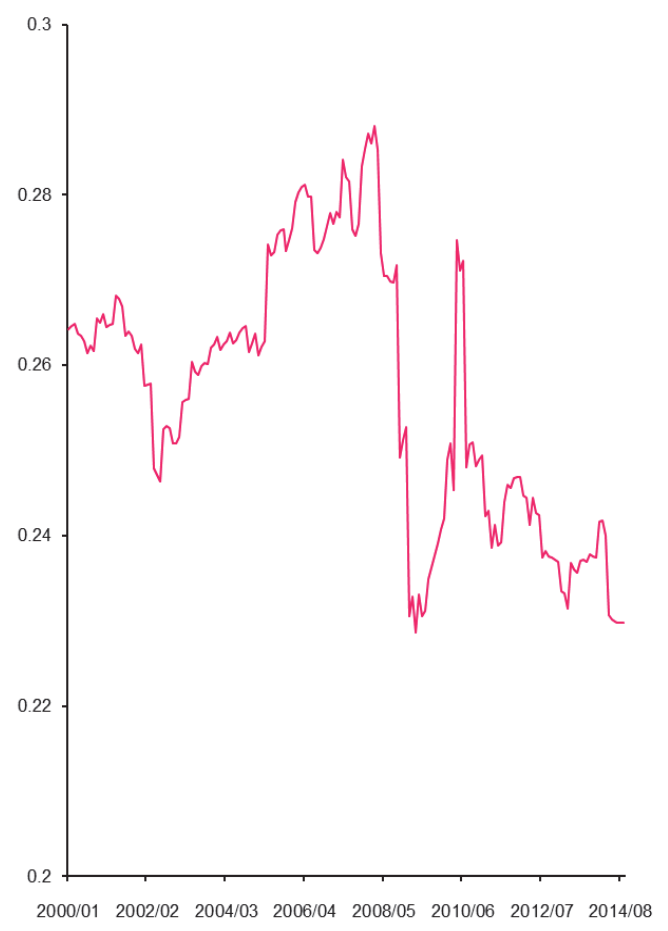

Panel B. Ordinary income to sales ratio

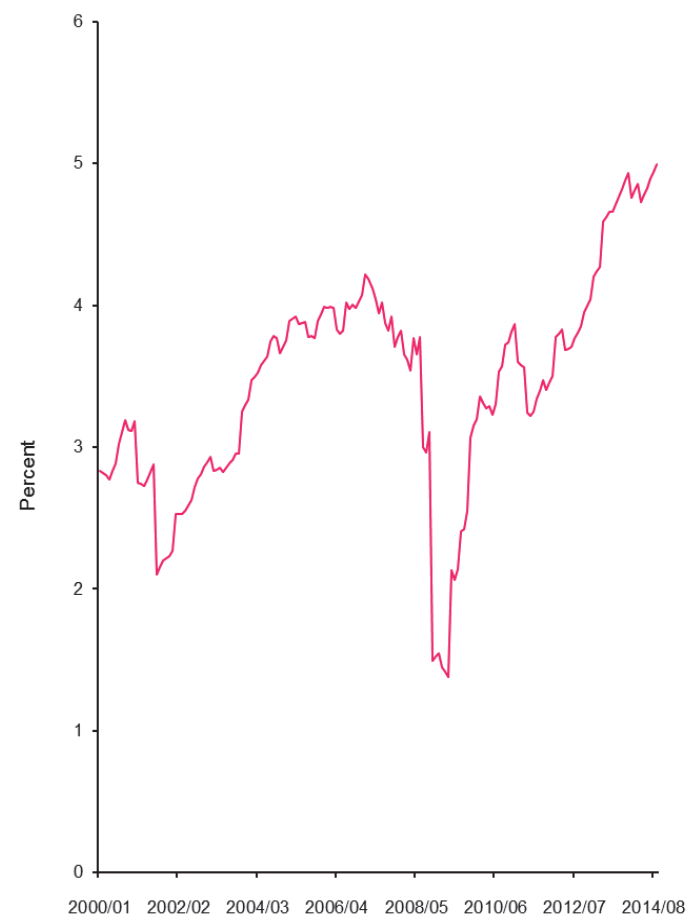

Panel D. Financial leverage

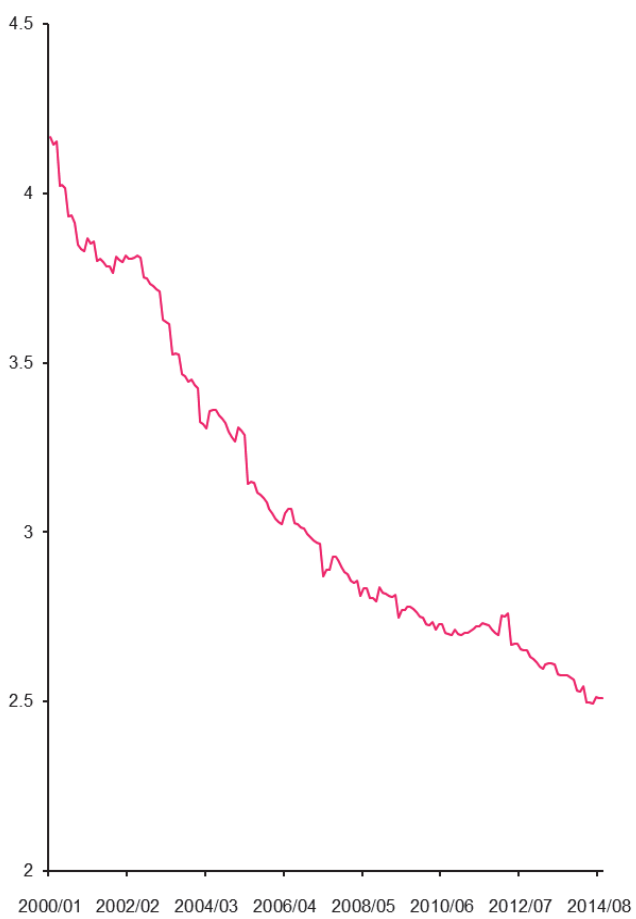


Panel E. Ordinary income per employee

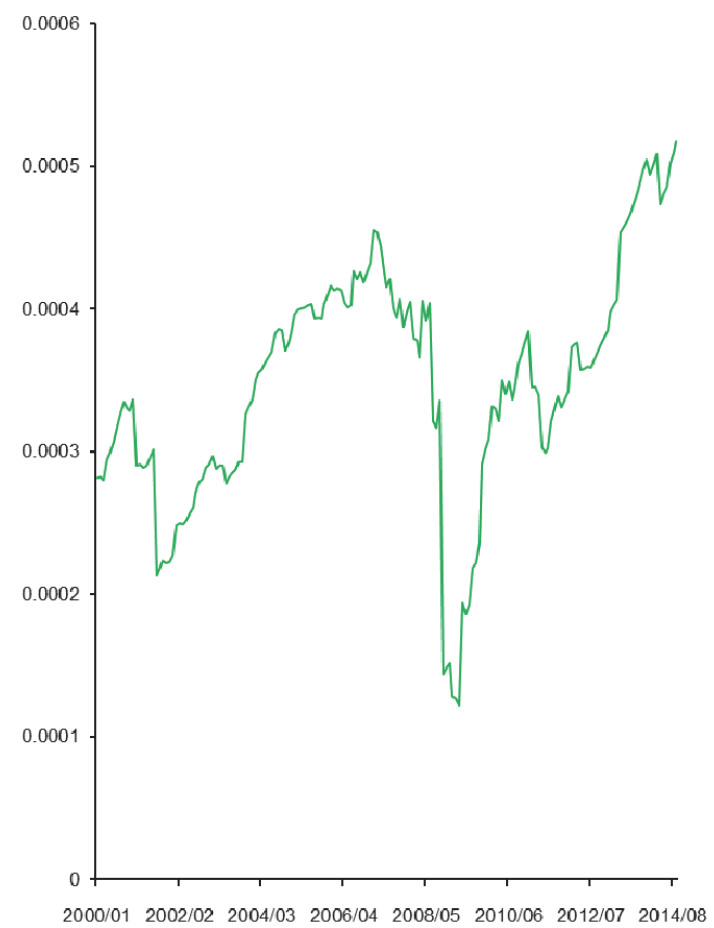

Panel G. Labor costs to sales ratio

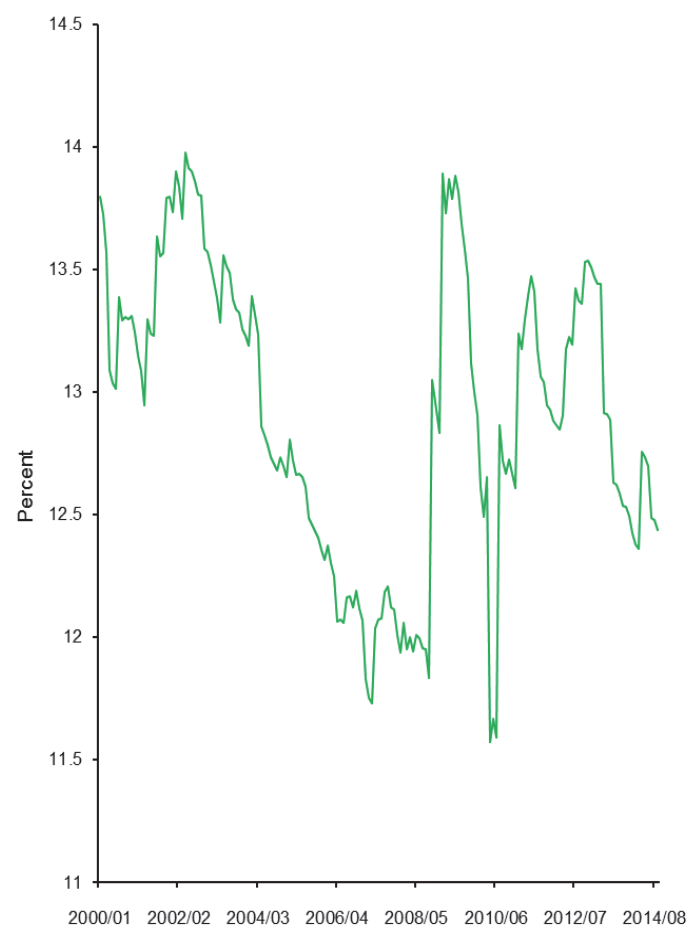

Panel F. Ordinary income to labor costs

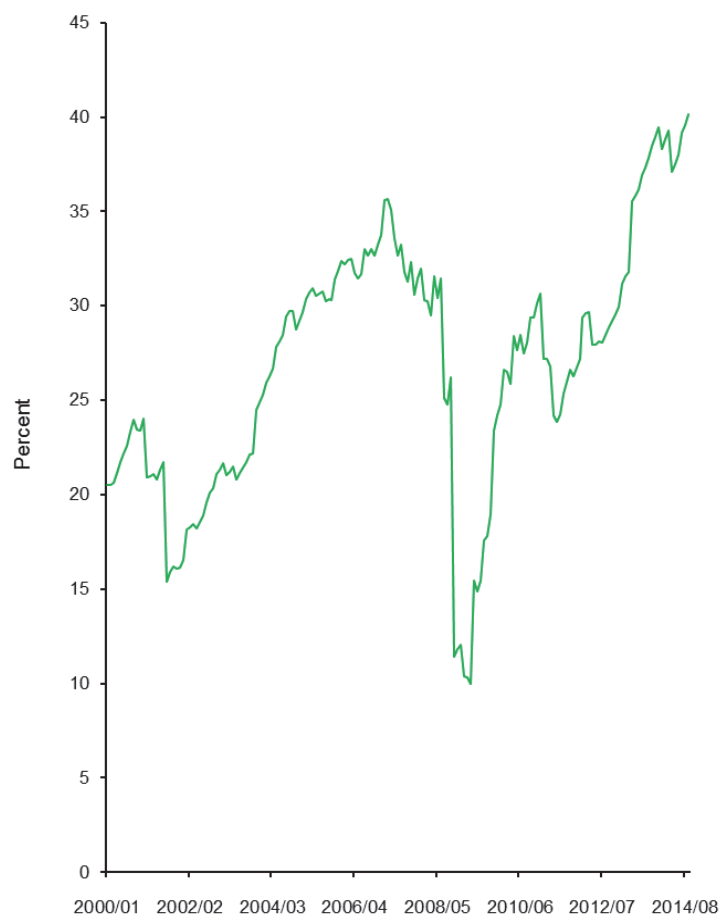

Panel H. Sales per employee

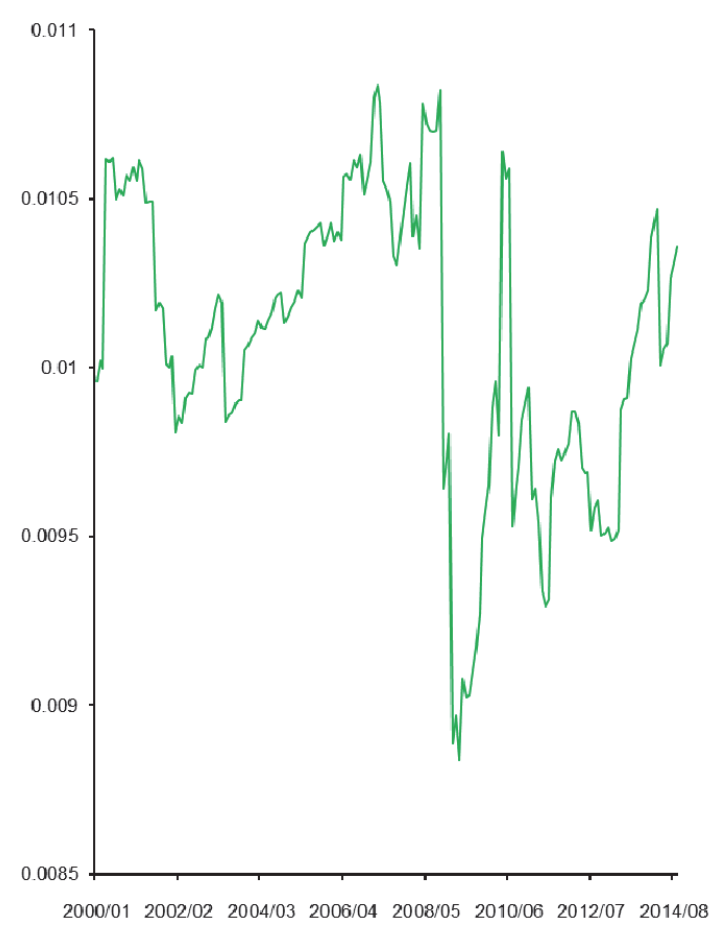

Figure 1. Time-series changes of the Japanese firms' financial ratios from January 2000 to September 2014: Decomposition of the ordinary income to equity capital ratio and the ordinary income per employee 


\section{Data}

This section documents our data and variables we analyze in this paper. All the data are supplied by the QUICK Corp., and all our variables are constructed by using the aggregate time-series data of the Japanese firms. More specifically, our first variable is 1) the ordinary income to equity capital ratio, whose unit is percent. Second is 2 ) the ordinary income to sales ratio, and the unit of this variable is also percent. Third is 3 ) the total asset turnover, which is the ratio of sales to total capital, and the unit of this variable is rotation. Moreover, 4) the financial leverage is our fourth variable and this variable is the ratio of total capital to equity capital. Our fifth variable is 5) the ordinary income per employee and our sixth variable is 6) the percentage ratio of the ordinary income to labor costs. Furthermore, our seventh variable is 7) the ratio of labor costs to sales, whose unit is percent, and 8) the sales per employee is our final variable. Regarding our samples analyzed in this study, they are monthly and our full sample period is from January 2000 to September 2014.

\section{Methodology}

We analyze the profitability of the Japanese firms from two viewpoints. Our first investigation of the corporate profitability is conducted by using the decomposition of the ordinary income to equity capital ratio into the three components as follows:

$$
O R I_{t} / E C A P_{t}=\text { ORI }_{t} / S A L S_{t} \times S A L S_{t} / T C A P_{t} \times T C A P_{t} / E C A P_{t} .
$$

In the above equation (1), ORI $I_{t}$ denotes the ordinary income at time $t, E C A P_{t}$ is the equity capital at time $t, S A L S_{t}$ denotes the total sales at time $t$, and $T C A P_{t}$ means the total capital at time $t$. Namely, equation (1) indicates that the ordinary income to equity capital ratio can be decomposed into the ordinary income to sales ratio, total asset turnover, and financial leverage.

Second, we also analyze the corporate profitability by using the decomposition of the ordinary income to employee ratio into the three components as follows:

$$
O R I_{t} / E M P_{t}=O R I_{t} / L C_{t} \times L C_{t} / S A L S_{t} \times S A L S_{t} / E M P_{t} .
$$

In the above equation (2), ORI denotes the ordinary income at time $t, E M P_{t}$ means the number of employee at time $t$, $L C_{t}$ denotes the labor costs at time $t$, and $S A L S_{t}$ is the total sales at time $t$. Namely, equation (2) suggests that the ordinary income per employee can be decomposed into the ratio of ordinary income to labor costs, labor costs to sales ratio, and the sales per employee.

\section{Overview}

Table 1 displays the descriptive statistics for our eight variables. This table shows the statistics of mean, median, maximum, minimum, standard deviation, skewness, kurtosis, and the number of observations as to the eight variables for our full sample period from January 2000 to September 2014. Figure 1 exhibits the monthly time-series trends of the eight variables for the above full sample period. Panels A to D display the state of the ordinary income to equity capital ratio expressed in equation (1). First, Panel A of Figure 1 suggests that the ordinary income to equity capital ratio of the Japanese firms quickly dropped during the Lehman shock period and after the shock, it recovered. Panel B of Figure 1 displays that the ordinary income to sales ratio of the Japanese firms also rapidly decreased around the Lehman shock and then the ratio recovered. Panel $\mathrm{C}$ of this figure indicates that the total asset turnover of the Japanese firms also quickly declined around the Lehman shock. Panel D of this figure suggests that the financial leverage of the Japanese firms continuously decreased for the entire sample period. Hence from Panels A to D in Figure 1, it is understood that the rapid drop of the ordinary income to equity capital ratio of the Japanese firms during the Lehman shock was due to the quick declines of the ordinary income to sales ratio and the total asset turnover of the Japanese firms around the Lehman shock period.

Next, Panels $\mathrm{E}$ to $\mathrm{H}$ exhibit the state of the ordinary income per employee of the Japanese firms expressed in equation (2). Panel E of Figure 1 firstly suggests that the ordinary income per employee of the Japanese firms rapidly declined during the period of the Lehman shock and this figure also shows that it afterwards recovered. Panel F of Figure 1 displays that the ordinary income to labor costs of the Japanese firms quickly decreased around the Lehman shock and after the shock, it recovered. Further, Panels $\mathrm{G}$ and $\mathrm{H}$ of this figure display the time-series changes of the labor costs to sales ratio and the sales per employee of the Japanese firms, respectively; graphically, these panels seem to show the unclear patterns of the time-series behavior of these two ratios. Therefore, from Panels $\mathrm{E}$ to $\mathrm{H}$ in Figure 1, we understand that the rapid decline of the ordinary income per employee of the Japanese firms during the period of the Lehman shock was mainly due to the quick drop of the ordinary income to labor costs of the Japanese firms around the Lehman shock period. 
Table 2. Descriptive statistics of the analyzed variables as to the Japanese firms before, during, and after the US Lehman shock: For the periods from January 2000 to August 2008, from September 2008 to August 2009, and from September 2009 to September 2014

\begin{tabular}{|c|c|c|c|c|}
\hline \multicolumn{5}{|c|}{ Panel A. From January 2000 to August 2008} \\
\hline & $\begin{array}{l}\text { Ordinary income to } \\
\text { equity capital ratio }\end{array}$ & $\begin{array}{l}\text { Ordinary income to } \\
\text { sales ratio }\end{array}$ & Total asset turnover & Financial leverage \\
\hline Mean & 2.9763 & 3.3341 & 0.2673 & 3.3911 \\
\hline Median & 3.0792 & 3.5122 & 0.2646 & 3.3393 \\
\hline Maximum & 3.4695 & 4.2137 & 0.2882 & 4.1668 \\
\hline Minimum & 2.0920 & 2.0990 & 0.2464 & 2.8044 \\
\hline Std. Dev. & 0.3583 & 0.5747 & 0.0097 & 0.3960 \\
\hline Skewness & -0.7422 & -0.3236 & 0.1613 & 0.1469 \\
\hline Kurtosis & 2.5013 & 1.8186 & 2.4242 & 1.6844 \\
\hline \multirow[t]{2}{*}{ Observations } & 104 & 104 & 104 & 104 \\
\hline & $\begin{array}{l}\text { Ordinary income per } \\
\text { employee }\end{array}$ & $\begin{array}{l}\text { Ordinary income to } \\
\text { labor costs }\end{array}$ & $\begin{array}{l}\text { Labor costs to sales } \\
\text { ratio }\end{array}$ & Sales per employee \\
\hline Mean & 0.0003 & 26.1774 & 12.8651 & 0.0103 \\
\hline Median & 0.0004 & 26.4584 & 12.8418 & 0.0104 \\
\hline Maximum & 0.0005 & 35.6379 & 13.9750 & 0.0108 \\
\hline Minimum & 0.0002 & 15.3922 & 11.7319 & 0.0098 \\
\hline Std. Dev. & 0.0001 & 5.6273 & 0.6625 & 0.0003 \\
\hline Skewness & -0.2602 & -0.1708 & -0.0344 & -0.0958 \\
\hline Kurtosis & 1.8464 & 1.6668 & 1.6227 & 1.9004 \\
\hline Observations & 104 & 104 & 104 & 104 \\
\hline
\end{tabular}

Panel B. From September 2008 to August 2009

\begin{tabular}{|c|c|c|c|c|}
\hline & $\begin{array}{l}\text { Ordinary income to } \\
\text { equity capital ratio }\end{array}$ & $\begin{array}{l}\text { Ordinary income to } \\
\text { sales ratio }\end{array}$ & Total asset turnover & Financial leverage \\
\hline Mean & 1.2969 & 1.9224 & 0.2402 & 2.7968 \\
\hline Median & 1.2085 & 1.8030 & 0.2340 & 2.8024 \\
\hline Maximum & 2.3602 & 3.1055 & 0.2718 & 2.8377 \\
\hline Minimum & 0.8893 & 1.3810 & 0.2287 & 2.7480 \\
\hline Std. Dev. & 0.4132 & 0.5436 & 0.0132 & 0.0268 \\
\hline Skewness & 1.4158 & 0.7812 & 1.2588 & -0.2684 \\
\hline Kurtosis & 4.6327 & 2.6809 & 3.5776 & 2.0318 \\
\hline \multirow[t]{2}{*}{ Observations } & 12 & 12 & 12 & 12 \\
\hline & $\begin{array}{l}\text { Ordinary income per } \\
\text { employee }\end{array}$ & $\begin{array}{l}\text { Ordinary income to } \\
\text { labor costs }\end{array}$ & $\begin{array}{l}\text { Labor costs to sales } \\
\text { ratio }\end{array}$ & Sales per employee \\
\hline Mean & 0.0002 & 14.4488 & 13.4072 & 0.0093 \\
\hline Median & 0.0002 & 13.4428 & 13.7069 & 0.0091 \\
\hline Maximum & 0.0003 & 26.2389 & 13.8920 & 0.0108 \\
\hline Minimum & 0.0001 & 9.9583 & 11.8353 & 0.0088 \\
\hline Std. Dev. & 0.0001 & 4.6503 & 0.6290 & 0.0006 \\
\hline
\end{tabular}




\begin{tabular}{|c|c|c|c|c|}
\hline Skewness & 1.4098 & 1.3438 & -1.4221 & 1.5529 \\
\hline Kurtosis & 4.6346 & 4.3855 & 4.1187 & 4.6695 \\
\hline Observations & 12 & 12 & 12 & 12 \\
\hline \multicolumn{5}{|c|}{ Panel C. From September 2009 to September 2014} \\
\hline & $\begin{array}{l}\text { Ordinary income to } \\
\text { equity capital ratio }\end{array}$ & $\begin{array}{l}\text { Ordinary income to } \\
\text { sales ratio }\end{array}$ & Total asset turnover & Financial leverage \\
\hline Mean & 2.5086 & 3.9318 & 0.2419 & 2.6563 \\
\hline Median & 2.4726 & 3.7789 & 0.2407 & 2.6960 \\
\hline Maximum & 3.0020 & 4.9937 & 0.2747 & 2.7746 \\
\hline Minimum & 1.6825 & 2.5509 & 0.2298 & 2.4939 \\
\hline Std. Dev. & 0.2881 & 0.6332 & 0.0091 & 0.0814 \\
\hline Skewness & -0.1016 & 0.2774 & 1.7377 & -0.5520 \\
\hline Kurtosis & 2.6889 & 1.8834 & 7.1994 & 2.0617 \\
\hline \multirow[t]{2}{*}{ Observations } & 61 & 61 & 61 & 61 \\
\hline & $\begin{array}{l}\text { Ordinary income per } \\
\text { employee }\end{array}$ & $\begin{array}{l}\text { Ordinary income to } \\
\text { labor costs }\end{array}$ & $\begin{array}{l}\text { Labor costs to sales } \\
\text { ratio }\end{array}$ & Sales per employee \\
\hline Mean & 0.0004 & 30.6093 & 12.8774 & 0.0098 \\
\hline Median & 0.0004 & 29.2178 & 12.8861 & 0.0098 \\
\hline Maximum & 0.0005 & 40.1554 & 13.5371 & 0.0106 \\
\hline Minimum & 0.0002 & 18.9434 & 11.5728 & 0.0093 \\
\hline Std. Dev. & 0.0001 & 5.3152 & 0.4543 & 0.0003 \\
\hline Skewness & 0.4262 & 0.4150 & -0.7582 & 0.5696 \\
\hline Kurtosis & 2.0586 & 2.0784 & 3.8513 & 2.6003 \\
\hline Observations & 61 & 61 & 61 & 61 \\
\hline
\end{tabular}

Notes: This table presents the descriptive statistics of the variables analyzed in this study. In this table, 'Std. Dev.' denotes the value of standard deviation. The samples are monthly and our three sub-sample periods are from January 2000 to August 2008 in Panel A, from September 2008 to August 2009 in Panel B, and from September 2009 to September 2014 in Panel C, respectively.

\section{Evidence: Before, During, and After the US Lehman Shock}

This section documents the further evidence as to the time-series characteristics of the profitability of the Japanese firms. To obtain more information, we divide our full sample period into three sub-sample periods, which are from January 2000 to August 2008, from September 2008 to August 2009, and from September 2009 to September 2014. Namely, Table 2 displays the descriptive statistics as to our eight variables for the periods before, during, and after the US Lehman shock (Panels A, B, and C, respectively).

Comparison of the results shown in Panels A, B, and C of Table 2 provides the following evidence. 1) First, around the Lehman shock, the ordinary income to equity capital ratio of the Japanese firms largely dropped (1.2969 of the mean value), and after the shock, it recovered (2.5086 of the mean value); however, it did not surpass the level before the Lehman shock (2.9763 of the mean value). 2) Second, during the Lehman shock, the ordinary income to sales ratio of the Japanese firms much declined (1.9224 of the mean value), and after the shock, it drastically improved ( 3.9318 of the mean value). As a result, it exceeded the level before the Lehman shock (3.3341 of the mean value). 3) Third, around the Lehman shock, the total asset turnover of the Japanese firms slightly decreased $(0.2402$ of the mean value), and after the shock, it somewhat restored ( 0.2419 of the mean value); however, it did not exceed the level before the Lehman shock ( 0.2673 of the mean value). 4) Fourth, the financial leverage of the Japanese firms continuously decreased regardless of the effects of the Lehman shock (As to the mean values, before the Lehman shock, 3.3911; during the shock, 2.7968; after the shock, 2.6563, respectively). 
Moreover, 5) around the Lehman shock, the ordinary income per employee ratio of the Japanese firms dropped ( 0.0002 of the mean value), and after the shock, it recovered ( 0.0004 of the mean value). The level of the ratio after the Lehman shock slightly exceeded the value before the Lehman shock (0.0003 of the mean value). 6) Sixth, during the Lehman shock, the ordinary income to labor costs of the Japanese firms much declined (14.4488 of the mean value), and after the shock, it largely restored (30.6093 of the mean value); the level surpassed the value before the Lehman shock (26.1774 of the mean value). 7) Seventh, around the Lehman shock, the labor costs to sales ratio of the Japanese firms somewhat increased (13.4072 of the mean value), and after the shock, it recovered (12.8774 of the mean value); the level was almost the same as the level before the Lehman shock (12.8651 of the mean value). 8) Eighth, during the Lehman shock, the sales per employee of the Japanese firms slightly declined (0.0093 of the mean value), and after the shock, it restored ( 0.0098 of the mean value); however, it did not surpass the level before the Lehman shock ( 0.0103 of the mean value).

\section{Conclusions}

This paper investigated the time-series changes of the profitability of the Japanese firms by focusing, in particular, on their differences in the periods before, during, and after the US Lehman shock. Evidence derived from our analyses using the Japanese time-series data is summarized as follows. 1) First, around the Lehman shock, the ordinary income to equity capital ratio, total asset turnover, and the sales per employee of the Japanese firms dropped, and after the shock, they recovered; however their levels did not exceed those before the Lehman shock. 2) Second, during the period of the Lehman shock, the labor costs to sales ratio of the Japanese firms unfavorably increased; however, after the shock, it recovered to almost the same level as that before the Lehman shock. 3) Third, during the Lehman shock, the ordinary income to sales ratio, ordinary income per employee, and ordinary income to labor costs of the Japanese firms declined; however, after the shock, they returned and improved to the levels that exceeded those before the Lehman shock. 4) Fourth, we further found that the financial leverage of the Japanese firms continuously decreased regardless of the effects of the Lehman shock.

Because of the considerable corporate efforts of the Japanese firms and the positive effects of the recent monetary easing policies conducted by the Bank of Japan, it is considered that the financial strength and profitability of the Japanese corporations recovered and much improved in the recent years. We consider that our concrete and clear findings as to the changing financial state of the Japanese firms are useful and informative not only for the Japanese investors but also for the international investors who are interested in the Japanese stock markets and the Japanese firms. Further improvements of the financial condition of the Japanese firms in the future shall be expected and they may have a positive effect on the Japanese stock markets as well. Further rigorous quantitative analysis of the related issues is one of our future works.

\section{Acknowledgements}

I am particularly grateful to the repeated kind invitation from the journal to write to this journal. I also appreciate the Japan society for the promotion of science, Zengin Foundation for Studies on Economics and Finance, and the Chuo university grant for special research for their generous financial assistance to this research. Moreover, I thank the anonymous referees of this journal for their very quick reviews and kind comments to this paper. Furthermore, I also thank Susan Sun for the kind and very quick assistance to my paper. Finally, I deeply thank the Editors of this journal for their kindness to this paper.

\section{References}

Ciampi, F. (2015). Corporate governance characteristics and default prediction modeling for small enterprises. An empirical analysis of Italian firms. Journal of Business Research, forthcoming. http://dx.doi.org/10.1016/j.jbusres.2014.10.003

Denis, D. J. (2011). Financial flexibility and corporate liquidity. Journal of Corporate Finance, 17, 667-674. http://dx.doi.org/10.1016/j.jcorpfin.2011.03.006

du Jardin, P. (2015). Bankruptcy prediction using terminal failure processes. European Journal of Operational Research, 242, 286-303. http://dx.doi.org/10.1016/j.ejor.2014.09.059

Lin, F., Liang, D., Yeh, C. C., \& Huang, J. C. (2014). Novel feature selection methods to financial distress prediction. Expert Systems with Applications, 41, 2472-2483. http://dx.doi.org/10.1016/j.eswa.2013.09.047

Rapp, M. S., Schmid, T., \& Urban, D. (2014). The value of financial flexibility and corporate financial policy. Journal of Corporate Finance, 29, 288-302. http://dx.doi.org/10.1016/j.jcorpfin.2014.08.004

Ritz, R. A., \& Walther, A. (2015). How do banks respond to increased funding uncertainty? Journal of Financial 
Intermediation, forthcoming. http://dx.doi.org/10.1016/j.jfi.2014.12.001

Sahin, A., \& Sahin, G. (2014). An overview on the exchange rate and liability dollarization in Turkey. The International Journal of Applied Economics and Finance, 8, 62-81. http://dx.doi.org/10.3923/ijaef.2014.62.81

Selahudin, N. F., Zakaria, N. B., Sanusi, Z. M. \& Budsaratragoon, P. (2014). Monitoring financial risk ratios and earnings management: Evidence from Malaysia and Thailand. Procedia - Social and Behavioral Sciences, 145, 51-60. http://dx.doi.org/10.1016/j.sbspro.2014.06.010

Tian, S., Yu, Y., \& Guo, H. (2015). Variable selection and corporate bankruptcy forecasts. Journal of Banking \& Finance, 52, 89-100. http://dx.doi.org/10.1016/j.jbankfin.2014.12.003

Tsuji, C. (2014a). Exploring the financial ratios: The case study of the famed chemical industry firms in the US. Case Studies in Business and Management, 1, 11-21. http://dx.doi.org/10.5296/csbm.v1i2.6434

Tsuji, C. (2014b). An empirical comparison of the corporate financing behavior: The case study of the major US and Japanese firms in the electrical-related industries. International Finance and Banking, 1, 18-29. http://dx.doi.org/10.5296/ifb.v1i2.6696 